\title{
MENAKAR DAMPAK FENOMENA PANDEMI COVID-19 TERHADAP PERBANKAN SYARIAH
}

\author{
Sumadi \\ Institut Teknologi Bisnis AAS Indonesia, Email : ahmadsumadi1924@gmail.com
}

\begin{abstract}
ABSTRAK
Covid-19 memiliki dampak yang signifikan terhadap perkembangan ekonomi dunia. Pandemi Covid-19 menjadi tantangan bagi dunia usaha, termasuk industri jasa keuangan perbankan. Hal ini menyebabkan sistem keuangan kita tergerus, termasuk bunga di bank konvensional. Penelitian ini dilakukan untuk mengetahui bagaimana manajemen strategi operasional yang dilakukan oleh perbankan syariah dalam menjalankan fungsinya sebagai lembaga intermediasi perbankan yaitu dalam hal penghimpunan dana dan penyaluran dana dalam menjalankan tugas dan fungsinya di tengah pandemi Covid-19. , serta sejauh mana perbankan syariah dapat menjalankan fungsi intermediasinya. Penelitian ini merupakan jenis penelitian kualitatif dengan pendekatan metode penelitian naturalistik karena penelitian dilakukan dalam kondisi alamiah. Pembahasan dilakukan dengan analisis deskriptif. Hasil penelitian menunjukkan dampak pandemi Covid-19 terhadap fungsi intermediasi perbankan, berdasarkan hasil studi di Bank Syariah Mandiri yaitu Pembiayaan dan DPK menunjukkan adanya fluktuasi. Di sisi pembiayaan, Bank Syariah Mandiri dari Januari hingga Maret 2020 cenderung mengalami peningkatan. Dari sisi penghimpunan dana (DPK), Bank Mandiri Syariah menunjukkan fluktuasi. Dampak Pandemi Covid-19 terhadap pengelolaan strategi operasional perbankan. Berdasarkan hasil studi di Bank Syariah Mandiri menunjukkan bahwa: Pertama, semua bank menerapkan stimulus ekonomi terkait restrukturisasi pembiayaan bagi nasabah yang terkena pandemi Covid-19 berdasarkan POJK No.11/POJK.03/2020. Kedua, pengembangan aplikasi digital mobile banking untuk bank syariah
\end{abstract}

Kata-kata kunci : Coronavirus Disease 2019; Perbankan Syariah; Manajemen Strategis; Perekonomian Nasional

\section{ABSTRACT}

Covid-19 has had a significant impact on world economic development. The Covid-19 pandemic is a challenge for the business world, including the banking financial services industry. This causes our financial system to be eroded, including the interest in conventional banks. This study was conducted to determine how the operational strategy management carried out by Islamic Banking in carrying out its function as a banking intermediary institution, namely in terms of raising funds and channeling funds carrying out their duties and functions amid during in the Covid-19 pandemic, as well as to what extent Islamic Banking can carry out its intermediation function. This research is a type of qualitative research with a naturalistic research method approach because the research is carried out in natural conditions. The discussion was carried out with descriptive analysis. The results showed the impact of the Covid-19 pandemic on the banking intermediation function, based on the results of a study at Bank Syariah Mandiri, namely Financing and TPF, the 
Bank showed a fluctuation. On the financing side, Bank Syariah Mandiri from January to March 2020 tends to increase. On the side of the collection of funds (DPK), Bank Mandiri Syariah shows fluctuation. The impact of the Covid-19 Pandemic on the management of banking operational strategies. Based on the results of a study at Bank Syariah Mandiri shows that: First, all banks implement economic stimulus related to restructuring financing for customers affected by the Covid-19 pandemic based on POJK No.11/POJK.03/2020. Second, the development of digital mobile banking applications for banks Sharia.

Keywords: Coronavirus Disease 2019; Sharia Banking; Strategic Management; National Economy

\section{PENDAHULUAN}

Pada saat ini dunia sedang mengalami fenomena yang luar biasa tak terkecuali negeri kita Indonesia, fenomena tersebut adalah pandemi corona virus (Covid-19). Wabah tersebut memberikan dampak ke seluruh sektor dan sendi kehidupan, tak terkecuali sistem keuangan perbankan syariah terkena dampaknya. Adanya karantina wilayah menyebabkan produk tidak terdistribusi dengan baik. Hal ini menyebabkan sistem keuangan tergerus, termasuk bunga yang ada di bank konvensional. Sebagaimana instruksi Gubernur Bank Indonesia (BI), perbankan diharap segera menurunkan bunga kredit (Laucereno, Sylke Febrina, 2020)

Covid-19 atau disebut Coronavirus Disease 2019 merupakan penyakit menular yang dapat menyebabkan penyakit paru-paru yang cukup serius. Kasus Covid-19 ditemukan pertama kali di Tiongkok pada November 2019. Covid-19 diketahui sebagai penyakit menular yang disebabkan oleh virus baru dengan tingkat persebaran sangat cepat. Seperti dilaporkan oleh Organisasi Kesehatan Dunia (WHO), total kasus Covid-19 yang terkonfirmasi di seluruh dunia adalah sebanyak 3.116.398 kasus dengan kematian 217.153 jiwa (29 April 2020). Indonesia adalah negara dengan jumlah kematian terbesar akibat Covid-19 di antara negara-negara ASEAN lainnya.

Covid-19 memberikan dampak signifikan terhadap perkembangan ekonomi dunia. Pandemi Covid-19 adalah tantangan bagi dunia bisnis, termasuk industri jasa keuangan perbankan. Berdasarkan data statistik perbankan Syariah pada Januari 2020, jumlah jaringan kantor Bank Umum Syariah adalah 1.922 cabang yang tersebar di berbagai wilayah di Indonesia yang didominasi oleh Pulau Jawa. Sejalan dengan wilayah terbanyak ditemukan Covid-19 yaitu di pulau Jawa (Statistik Perbankan 
Syariah, Januari 2020). Ini menunjukkan bahwa sebagian besar Kantor Bank Syariah berada di zona merah.

Penelitian yang dilakukan oleh Michael McAleer menyimpulkan bahwa kemampuan keamanan kesehatan global di 195 negara. Indeks GHS mencantumkan negara-negara yang terbaik siap untuk epidemi atau pandemi. Sementara negara-negara berpenghasilan tinggi melaporkan skor rata-rata 51,9, Indeks menunjukkan bahwa secara kolektif, kesiapan internasional untuk epidemi dan pandemi masih sangat lemah (Michael McAleer, 2020).

Terlebih lagi penyebaran virus Covid-19 yang sangat cepat ke negara-negara lainya termasuk Indonesia juga memperparah keadaan ekonomi. Pasalnya pemerintah telah mengeluarkan sejumlah kebijakan yang digunakan untuk memutus rantai penyebaran virus seperti pembatasan sosial dan penutupan sejumlah perusahaan yang membuat masyarakat membatasi tingkat konsumsinya karena minimnya pemasukan atau bahkan sama sekali tidak ada pemasukan sementara kebutuhan sehari-hari terus berjalan. Sejumlah kebijakan dikeluarkan untuk meringankan beban rakyat termasuk pemberian subsidi listrik dan pemberian bantuan tunai setiap bulannya. Hal ini membuat anggaran negara yang terus berkurang sementara tidak ada pemasukan yang membuat negara melakukan hutang dalam jumlah besar termasuk meluncurkan global kupon bon guna menstabilkan keadaan perekonomian di Indonesia (Syukra, Ridho, 2020).

Perbakan syariah sebagaimana fungsinya sebagai lembaga intermediasi atau perantara keuangan yang mempertemukan antara masyarakat yang kelebihan dana dengan masyarakat yang kekurangan dana dituntut untuk dapat berinteraksi dengan orang banyak, namun di sisi lain ancaman terhadap paparan virus Covid-19 menjadi tantangan bagi lembaga perbankan tersebut, berbagai penelitian tentang dampak Covid-19 pada industri keuangan telah dilakukan oleh Kashif Malik (2020) dengan obyek industri keuangan mikro. Zbigniew Korzeb dan Samaniego (2019) dengan obyek perbankan syariah dengan fokus kajian penelitian pada fungsi intemediasi bank Islam.

Penelitian ini dilakukan bertujuan untuk mengetahui bagaimana manajemen strategi operasional yang dilakukan perbankan syariah dalam 
menjalankan fungsinya sebagai lembaga intermediasi perbankan yaitu dari sisi penghimpunan dana dan penyaluran dana melaksanakan tugas dan fungsinya di tengah pandemi Covid-19, serta sejauhmana perbankan syariah dapat menjalankan fungsi intermediasinya. Berdasarkan data statistik Perbankan Syariah pada Maret 2020 dari sisi penghimpunan Dana Bank Umum Syariah secara nasional mngalami penurunan menjadi 234.240 Miliar di Maret 2020.

\section{METODE PENELIITIAN}

Penelitian ini merupakan jenis penelitian kualitatif dengan pendekatan metode penelitian naturalistik karena penelitiannya dilakukan pada kondisi yang alamiah. Pembahasan dilakukan dengan analisis deskriptif, penelitian dilakukan pada objek yang alamiah yaitu obyek yang berkembang apa adanya, tidak dimanipulasi oleh penelitian dan kehadiran penelitian tidak mempengaruhi dinamika obyek tersebut. Jadi apa yang terjadi dilapangan tanpa merubah atau memperbaiki data, data itulah yang di analisis kemudian dituangkan dalam laporan penelitian (Sugiyono, 2011).

Obyek Penelitian ini adalah Bank Umum Syariah. Bank Umum Syariah dipilih dengan pertimbangan sebagai salah satu lembaga jasa keuangan yang memberikan kontribusi besar pada pertumbuhan ekonomi melalui bantuan permodalan. Sampel penelitian diperoleh dengan menggunakan teknik purposive sampling. Purposive sampling adalah pengambilan sampel berdasarkan kriteria Bank Umum Syariah yang mempublikasikan laporan keuangan dengan baik dari Januari hingga Maret 2020 yaitu Bank Syariah Mandiri.

\section{HASIL DAN PEMBAHASAN}

\section{Perkembangan Covid-19}

Covid-19 saat ini menjadi isu kesehatan yang paling mengkhawatirkan di penjuru dunia, termasuk diantaranya di Indonesia. Penanggulangan yang dilakukan suatu daerah bahkan suatu negara dilakukan sebagai upaya untuk meminimalisir penyebaran penyakit tersebut salah satunya adalah dengan kebijakan Lock down. Penelitian terbaru ternyata ditemukan bahwa diameter Covid-19 diperkirakan sampai 125 nanometer atau 0,125 mikrometer. Itu artinya satu mikrometer sama dengan 1000 
nanometer. Sungguh sangat kecil sekali dan tak mungkin pandangan telanjang manusia dapat menginderanya. Bahkan karena ukurannya yang sangat mikro, sehingga manusia tak bisa berpikir untuk meremehkan virus tersebut. Karena Covid-19 ini dapat bertahan lebih dari 10 menit pada permukaan, termasuk diantaranya adalah di tangan manusia sekalipun. Lebih dari itu bahkan badan kesehatan Perserikatan Bangsa Bangsa, atau biasa yang disebut WHO menyebut, bahwa virus corona baru (Covid-19) ini dapat bertahan hidup selama beberapa jam, hingga bisa beberapa hari dan dapat bertahan hidup pada suhu 26-27 derajat celcius (BBC News, 2020).

Dunia gempar ketika berita terkait virus corona pertama kali terdengar, banyak negara-negara yang panik akan penyebaran virus tersebut, namun ada pula yang menanggapi dengan santai wabah virus corona tersebut. Bencana non alam ini tentu saja bukan pertama kalinya dihadapi negara-negara di dunia. Sejarah mencatat pernah ada sebelumnya beberapa virus yang juga dapat mengancam nyawa jika tidak segera ditangani seperti virus Ebola, SARS, H5N1 atau Flu Burung, HIV, MERS, dan lain-lain. Virus corona baru atau Covid-19 yang telah dinyatakan sebagai pandemik oleh Badan Kesehatan Dunia (WHO) dan berimplikasi politik. Salah satunya bagaimana pejabat Tiongkok mempertanyakan ulang soal asal usul virus yang telah menewaskan lebih dari 4.200 orang di dunia tersebut. Dalam hal ini, sejumlah warganet Tiongkok turut berdebat tentang dari mana sesungguhnya COVID-19 berasal. WHO sendiri telah menegaskan bahwa Tiongkok yang kali pertama melaporkan keberadaan virus itu pada awal Januari lalu setelah muncul kasus di Wuhan, Provinsi Hubei. Dari 128.343 kasus, 80.932 terjadi di Tiongkok.

Amerika Serikat dan China sempat saling tuding soal asal usul pandemi Covid -19. Presiden Donald Trump menyebutnya sebagai 'Chinese Virus' alias virus dari Tiongkok. Sebelumnya, juru bicara Kementerian Luar Negeri China, Zhao Lijian bikin geger saat mengatakan, "bisa jadi US Army atau tentara AS yang membawa epidemi itu ke Wuhan". Perseteruan itu pun dipertegas dalam sebuah wawancara dengan $C N B C$, Menteri Luar Negeri Amerika Serikat Mike Pompeo bersikap rasis dengan menyebut Covid-19 sebagai "virus corona Wuhan." Padahal WHO sendiri pernah menegaskan bahwa memakai nama wilayah untuk menyebut suatu virus adalah sesuatu yang tidak diperkenankan. Ini karena potensi stigma dan xenofobia yang muncul sangat merugikan. Tetapi, Presiden Amerika 
Serikat Donald Trump justru mengeluarkan komentar bahwa COVID-19 adalah "virus asing" (BBC News, 2020). Akan tetapi berdasarkan hasil penelitian yang dipublikasikan di jurnal ilmiah, Nature Medicine mematahkan anggapan China maupun kubu Donald Trump, sekaligus membantah teori konspirasi yang menyebut virus pemicu Covid-19 atau SARS-CoV-2 adalah buatan manusia atau senjata biologis yang sengaja diciptakan. Seperti dikutip dari situs www.sciencedaily.com, hasil analisis data publik terkait sekuens atau urutan genom (genome sequence) dari SARS-CoV-2 dan virus terkait tidak ditemukan bukti bahwa virus tersebut diciptakan di laboratorium. "Dengan membandingkan data sekuens genom yang tersedia untuk strain coronavirus yang telah diketahui, kami meyakini bahwa SARS-CoV-2 berasal dari proses yang alami," kata Kristian Andersen, associate professor imunologi dan mikrobiologi di Scripps Research, yang menjadi salah satu penulis laporan studi tersebut. Selain Andersen, sejumlah ilmuwan lain juga ikut andil dalam studi dan penulisan makalah berjudul, 'The proximal origin of SARS-CoV-2' itu. Termasuk, Robert F. Garry dari Tulane University, Edward Holmes dari University of Sydney, Andrew Rambaut dari University of Edinburgh, dan W. Ian Lipkin dari Columbia University. Virus Corona (coronavirus) adalah keluarga besar (family) virus yang dapat menyebabkan penyakit dengan tingkat keparahan yang luas.

Pada Tahun 1960-an, telah dikategorisasi penyakit parah pertama, yang diketahui disebabkan oleh Virus Corona adalah Severe Acute Respiratory Syndrome (SARS) yang mulai menjadi epidemi di China pada 2003. Sementara, pada kategorisasi penyakit kedua yang mewabah adalah Middle East Respiratory Syndrome (MERS) yang bermula di Arab Saudi pada 2012. Pada 31 Desember 2019 pihak berwenang China memberitahukan pada Badan Kesehatan Dunia (WHO) mengenai wabah virus corona baru yang menyebabkan penyakit parah, yang kemudian dinamai SARS-CoV-2. Hingga kini, virus tersebut memicu pandemi Covid-19 yang menyebar ke seluruh benua, kecuali Antartika. Hingga Rabu 18 Maret 2020 pukul 18.33, tercatat ada 201.530 kasus positif Virus Corona, 8.007 pasien meninggal dunia, dan 82.034 lainnya pulih. Kasus meluas karena penularan bisa terjadi antar-manusia. Tak lama setelah epidemi terjadi, para ilmuwan China mengurutkan genom SARS-CoV-2 dan menyediakan data bagi para peneliti di seluruh dunia (BBC News, 2020). Dalam hal ini, Andersen dan para 
koleganya menggunakan data sekuens tersebut untuk mengeksplorasi asal mula dan evolusi SARS-CoV-2 dengan fokus ke sejumlah fitur khas virus tersebut. Sedangkan para ilmuwan menganalisis pola genetik (genetic template) protein lonjakan (spike proteins), armature atau pelindung di bagian luar virus yang digunakannya untuk menangkap dan menembus dinding luar sel manusia dan hewan. Lebih khusus, mereka berfokus pada dua fitur penting dari protein lonjakan: domain pengikat reseptor atau receptor-binding domain ( $\mathrm{RBD})$, sejenis pengait yang menempel pada sel inang, dan cleavage site yang memungkinkan virus untuk membuka celah dan memasukkan sel inang.

Disampaikan oleh Badan Pusat Statistik (BPS) tahun lalu mencatat pertumbuhan ekonomi RI mendekati ke posisi tahun 2016 yang tumbuh $5,03 \%$ tahun ini pertumbuhan ekonomi sebesar 5,02\%, Dan lebih lambat dari tahun-tahun sebelumnya, dan. Sebelumnya, Fitch Solutions Country Risk and Industry Research merilis outlook bulanan perekonomian ditengah pandemic covid-19. Dalam rilisnya tersebut, Fitch Solutions memprediksi perekonomian global dan juga Indonesia. Pertumbuhan ekonomi global di 2020 diprediksi berada diantara 0\% dan -0,5\%. Fitch Solutions juga melihat perekonomian global baru mulai keluar dari resesi diakhir kuartal IV-2020. Diperkirakan perekonomian global mulai bisa keluar dari resensi diakhir kuartal-IV, dilihat dari resesi-resesi di akhir kuartal-IV, dilihat dari resesi-resesi yang terjadi sejak 1948 yang rata- rata berlangsung selama 10 bulan hingga 12 bulan. Proyeksi tersebut diberikan dengan asumsi pademi Covid-19 mampu dihentikan dalam dua bulan ke depan. Adapun untuk Indonesia, mesti disebut menjadi yang 4,2\%, pada akhir tahun nilai tukar rupiah berada dikisaran $\mathrm{Rp}$ 16.750/US\$. Melihat prediksi pertumbuhan ekonomi Indonesia oleh Fitch Solutions tersebut terbilang cukup optimistis dibandingkan prediksi yang diberikan institusi lainnya. Bahkan Fitch Ratings, lembaga terpisah dari Fitch Solutions, dalam laporan berjudul "Global Economic Outlook-Crisis Update: 2 April 2020" memperkirkan PDB Indonesia tahun ini hanya tumbuh $2 \%$. Skenario pertumbuhan ekonomi saat konferensi, Skenario di kuartal I-2020 4,7\% kemudian dikuartal II-2020 1,1\% dan di kuartal III-2020 mencapai 1,3\% dan kemudian meningkat di kuartal IV-2020 2,4\%.

2. Strategi Perbankan Syariah

Kebijakan untuk meminimalkan dampak Covid-19, termasuk di 
sektor industri perbankan. Pemerintah melalui Otoritas Jasa Keuangan mengeluarkan Kebijakan Stimulus Perekonomian Nasional Sebagai Kebijakan Countercylical Dampak Penyebaran Coronavirus Disease 2019, penerbitan POJK No.11/POJK.03/2020. Kebijakan stimulus yang dimaksud terdiri atas kebijakan penilaian kualitas pembiayaan hanya didasarkan pada ketepatan pembayaran pokok dan margin/ bagi hasil/ujrah dengan pembiayaan mencapai 10 Miliar dan Skema Restrukturisasi pembiayaan. POJK No. 18/POJK.03/2020 mengambil langkah-langkah untuk menjaga stabilitas sistem keuangan, terutama di sektor perbankan, ancaman pelemahan ekonomi akibat pandemi Covid-19. OJK memberikan perintah kepada Bank untuk yang Pertama, melakukan merger, konsolidasi, pengambilalihan, dan atau integrasi. Kedua, menerima merger, konsolidasi, akuisisi, atau integrasi (Otoritas Jasa Keuangan, 2019).

Kebijakan tentang industri perbankan yang dikeluarkan oleh otoritas selama PSBB (SP 26/DHMS/ OJK/IV/2020). Menurut Siaran Pers dalam Operasi Industri Jasa Keuangan Selama Periode Implementasi PSBB di Berbagai Daerah. Isinya bahwa OJK meminta lembaga jasa keuangan untuk bekerja dengan jumlah minimum karyawan sesuai dengan protokol kesehatan di tempat kerja Lembaga layanan keuangan harus mematuhi prosedur PSBB untuk diimplementasikan, seperti physical distancing, mengurangi layanan dengan tatap muka dan sebagai gantinya perbankan dapat memaksimalkan penggunaan teknologi dan selalu menjaga kesehatan, sedangkan untuk peraturan pekerjaan dari rumah, diserahkan kepada masing-masing Lembaga Jasa Keuangan, sedangkan untuk pelaksanaan teknis pemberian akses dengan menunjukkan identitas karyawan dan Surat Tugas (Yuliana, 2020).

Sebelum adanya wabah Covid-19, Indonesia sudah pernah mengalami kemerosotan ekonomi yaitu pada tahun 1997, 1998 sampai 1999 saat terjadi krisis moneter akibat anjloknya harga minyak di dunia. Saat ini kelesuan ekonomi juga tengah terjadi akibat menyebarnya covid 19 awal tahun baru 2020 yang berasal dari Cina. Covid-19 sendiri mulai melanda di Indonesia pada bulan maret 2020 dan terus mengalami peningkatan hingga sekarang. Berbagai upaya dilakukan pemerintah untuk mengendalikan penyebaran virus ini dan menyetabilkan ekonomi.Pengendalian virus Covid-19 dilakukan mulai dari pemberlakuan semi lock down hingga PSBB sementara penyetabilan ekonomi dilakukan dengan penurunan suku 
bunga acuan, pemberian subsidi hingga peluncuran kupon global bon (Syukra, Ridha, 2020).

Langkah kebijakan yang akurat terhadap penyelamatan perekonomian sangat penting dilakukan oleh pemerintahan. Karena dampak terhadap masyarakat, perusahaan dan lainnya, karena berhubungan terhadap kesejahteraan. Maka dari itu kebijakan perekonomian memiliki tujuan-tujuan yang berkaitan terhadap ekonomi Islam. Adapun tujuantujuan tersebut adalah berusaha memaksimasi tingkat pemanfaatan sumber-sumber. Tujuan ini berarti mencakup secara utuh dan menyeluruh sumber-sumber alam dan manusia yang ada dinegara yang bersangkutan. Memanfaatkan sumberdaya yang ada berarti tanda bersyukur kepada Allah. Menurut Monzer Kafh pemerintah harus bertanggung jawab untuk membangun karena tiga tujuan yaitu (1) menjamin standar hidup minim bagi warga negaranya (Monzher Kahf, 1995). Ini dapat di buktikan bahwa pemerintah bersama kementerian ketenagakerjaan membuat peraturan mengenai perlindungan terhadap para pekerja karena efek dari covid 19 ini sesuai dengan sesuai surat Edaran Menteri Ketenagakerjaan RI No. M/3/ HK.04/III/2020 tentang Perlindungan Pekerja dan Kelangsungan Usaha dalam Pencegahan dan Penanggulangan Covid-19. (2) diwajibkan menggunakan sebagian sumber yang diperolehnya untuk kegiataan penyiaran pesan-pesan Islam ke seluruh dunia khususnya juga dalam meningkatkan peran perbankan syariah (Kompas,2020).

Tujuan dari kebijakan adalah kesejahteraan dari dampak pelaksanaan perbankan syariah di Indonesia sudah dirasakan oleh masyarakat. Peran perbankan syariah sudah dapat mengurangi kesenjangan sosial yang terjadi di Indonesia dan menjadi stimulus pertumbuhan ekonomi. Dimana pelarangan pemakaian riba menjadikan peluang untuk perbankan syariah dalam menciptakan perekonomian yang sehat dan positif. Menganggap nasabah sebagai mitra kerja dengan membagi risiko kerugian dan keuntungan sehingga apabila terjadi kerugian dalam usaha nasabah atau masyarakat mereka merasa diringankan sebab bank juga menanggung resiko kerugian. Menurut Hasanah, peran bank syariah memberikan dukungan atas suksesnya usaha nasabah, sehingga berdampak bagi kesejahteraan (Hasanah, 2014:23). Identifikasi sejahtera pada nasabah dapat dilihat daripeningkatan usaha nasabah, dan terpenuhinya kebutuhan konsumen dari hasil transaksi tersebut. 
Kondisi ketidakstabilan ekonomi juga akan dirasakan apabila mengenakan produk perbankan syariah. Kestabilan ekonomi bisa terjadi sebab perbankan syariah tidak terpengaruhi oleh naik turunnya suku bunga dimana ketentuan nisbah tetap yang disepakati dari awal akad. Dampak dari hal tersebut, masyarakat akan terus produktif dari dana yang telah disalurkan oleh bank syariah. Masyarakat juga mendapatkan kenyamanan dimana dengan menggunakan layanan perbankan syariah dapat menghindari larangan-larangan agama. Industri Perbankan Syariah memiliki peran yang strategis dalam pembangunan ekonomi rakyat, berkontribusi dalam melakukan transformasi perekonomian pada aktivitas ekonomi produktif, bernilai tambah dan inklusif tetapi di masa Pandemi Covid-19 ini industri perbankan syariah harus bergerak cepat untuk beradaptasi dengan membuat strategi, inovasi baru serta mitigasi risiko yang tepat dan cermat serta menggunakan strategi kreatif untuk bertahan dalam menghadapi pandemi Covid-19 yang membuat kondisi perekonomian tak menentu. Artinya industri perbankan syariah mempunyai tantangan yang cukup signifikan, namun Industri Perbankan Syariah harus melihat permasalahan penyebaran virus ini sebagai tantangan yang harus dirubah menjadi sebuah kesempatan untuk bisa lebih baik. Maka dari itu, sudah saatnya Perbankan Syariah mulai merevisi kembali strategi, mengingat tidak ada yang mengetahui kapan Covid-19 akan berakhir. Berangkat dari hal tersebut, penelitian ini dilakukan dengan tujuan untuk memaparkan tantangan perbankan syariah menghadapi pandemi Covid-19 di Indonesia.

Sebagai lembaga intermediasi, denyut bisnis bank sangat bergantung pada perputaran roda ekonomi, yang digerakkan oleh aktivitas masyarakat. Sehingga ketika masyarakat 'dipaksa' tinggal di rumah maka bank juga terpaksa rela untuk kehilangan potensi pendapatan. Industri perbankan syariah setidaknya ada 8 item yang terdampak di saat pandemi, yaitu pertumbuhan pembiayaan, Financing to Deposit Ratio (FDR), Capital Adequacy Ratio (CAR), likuiditas, Net Interest Margin (NIM), kualitas aset, operasional, dan customer relationship. Menurut Penulis tantangan utama yang dihadapi adalah dari sisi pembiayaan, karena Bank tidak bisa melakukan ekspansi seiring dengan penurunan permintaan, sehingga bank fokus pada strategi bersamaan dengan implementasi kebijakan restrukturisasi pembiayaan serta penyaluran yang mayoritas disalurkan kepada 
sektor yang bukan merupakan lapangan usaha, seperti pemilik rumah tinggal Rp 83,7 Triliun, pemilik peralatan rumah tangga lainnya termasuk multiguna $\mathrm{Rp}$ 55,8 Triliun, namun penyaluran pembiayaan perbankan syariah juga cukup besar untuk sektor lapangan usaha, seperti perdagangan besar dan eceran mencapai Rp37,3 triliun, konstruksi Rp32,5 triliun dan industri pengolahan sebesar Rp27,8 triliun. Maka dari itu, perbankan syariah harus tetap selektif dalam menyalurkan kredit ditengah pandemi sehingga mampu menjaga rasio non performing financing (NPF) dengan mengukur omzet perusahaan dan memulai revisi target pertumbuhan, memangkas target pembiyaan menjadi lebih konservatif.

Selain itu, peningkatan risiko dan merosotnya kegiatan akibat pandemi, tidak saja mempengaruhi untuk memberikan pembiayaan namun kenaikan risiko dalam non performing loan/non performing financing akan menentukan apakah bisa bertahan atau bangkit kembali. Munculnya peningkatan risiko tersebut tak luput dari adanya pembatasan aktivitas sosial dan ekonomi demi menekan penyebaran pandemi Covid-19 yang kian hari justru meningkat. Pembatasan aktivitas sosial dan ekonomi menyebabkan turunnya kegiatan, risiko tersebut dihadapi perbankan secara umum dan perbankan syariah tentu harus diwaspadai. Risiko peningkatan kesulitan likuiditas, penurunan aset keuangan, penurunan profitabilitas dan risiko pertumbuhan perbankan syariah yang melambat atau bahkan negatif.

Pengamat ekonomi Syariah Azis Setiawan menyampaikan profitabilitas bank syariah akan mulai tertekan pada kuartal II 2020. Hal ini kemudian akan berdampak terhadap kinerja keuntungan perbankan tahun ini yang diperkirakan melemah dibandingkan tahun lalu mengingat pandemi Covid-19 ini tidak ada yang tahu sampai kapan berakhir, maka industri perbankan syariah tetap menerapkan prinsip kehati-hatian dalam kerangka mitigasi manajemen risiko yang kuat untuk mendukung kebijakan-kebijakan Pemerintah dalam menjaga stabilitas ekonomi Indonesia. Dengan adanya pembatasan kegiatan akibat pandemi Covid-19 setiap industri harus siap bergerak menghadapi perubahan-perubahan yang dinamis tidak terkecuali pada industri perbankan syariah, sesuai arahan dan anjuran pemerintah untuk menjaga jarak fisik (physical distancing) dan tetap di rumah Work/Study From Home serta memberlakukan Pembatasan Sosial Berskala Besar atau PSBB, anjuran pemerintah tersebut 
untuk mengurangi dan meminimalisir risiko peluang penularan Covid-19. Tantangan Industri perbankan syariah Pertama menjaga jarak fisik (Physical Distancing), Industri perbankan syariah dituntut untuk melayani nasabah dari rumah, bank syariah harus menyesuaikan pola bisnis akibat pandemi Covid-19, perbankan syariah dituntut melayani nasabah melalui digitalisasi layanan bank, baik layanan digitalisasi dalam penghimpunan dana maupun pembiayaan. Senada dengan Gubernur Bank Indonesia (BI) Perry Warjiyo langkah cepat dan adaptif (Azis, 2020).

Lebih dari itu semuanya, sesungguhnya apa yang dilakukan perbankan syariah tidak hanya memberikan kesejahteraan di dunia namun juga di akhirat. Permasalahan yang ditimbulkan karena adanya sistem bunga (riba), yaitu: adanya ketidakadilan dalam praktik perekonomian. Hal itu terasa pada saat Covid-19 melanda. Nasabah sulit mendapatkan keuntungan, sementara bunga bank wajib dibayar tiap bulannya. Bunga pada bank konvensional menjadi pendukung kredit macet di perbankan konvesional, tingginya rate kredit dan berlipat-lipat mengakibatkan kesulitan nasabah membayar, kehidupan ekonomi masyarakat tidak menentu. Hal ini menjadikan bunga menjadi salah satu faktor penyebab inflasi dan munculnya kesenjangan ekonomi dan konglomerasi kekayaan. Karena hal itulah DSN dalam fatwanya No 1 tahun 2004 menghukumi bunga adalah riba. Usaha untuk meng hindark an mas y a r a k a t menggunakan praktik riba di atas, bank syariah memberikan solusi dengan menerapkan sistem bagi hasil. Sistem bagi hasil memberikan efek keadilan dan kesejahteraaan. Dampak keadilan ekonomi menjadikan ekonomi merata, inflasi akan menyesuaikan karena daya beli masyarakat meningkat, dan dengan sejahtera maka masyarakat akan terhindar dari hutang yang bersifat konsumtif.

Regulator mengeluarkan kebijakan untuk meminimalkan dampak Covid-19, termasuk di sektor industri perbankan. Pemerintah melalui Otoritas Jasa Keuangan mengeluarkan Kebijakan Stimulus Perekonomian Nasional Sebagai Kebijakan Countercylical Dampak Penyebaran Coronavirus Disease 2019, penerbitan POJK No.11/POJK.03/2020. Kebijakan stimulus yang dimaksud terdiri atas kebijakan penilaian kualitas pembiayaan hanya didasarkan pada ketepatan pembayaran pokok dan margin/bagi hasil/ ujrah dengan pembiayaan mencapai 10 Miliar dan Skema Restrukturisasi pembiayaan. Restrukturisasi pembiayaan adalah bantuan pelunasan 
pinjaman. Restrukturisasi bukanlah penghapusan, tetapi memberikan kelonggaran untuk melunasi pembayaran utang. Pinjaman masih harus dibayar tetapi diberikan keringanan Relaksasi dari pengaturan ini berlaku untuk debitur Non-UKM dan UKM, dengan masa berlaku hingga satu tahun dari 13 Maret 2020 hingga 31 Maret 2021. Pelaksanaannya tergantung pada kebijaksanaan masing-masing bank (Otoritas Jasa Keuangan, 2019).

POJK No. 18/POJK.03/2020 mengambil langkah-langkah untuk menjaga stabilitas sistem keuangan, terutama di sektor perbankan, ancaman pelemahan ekonomi akibat pandemi Covid-19. OJK memberikan perintah kepada Bank untuk yang Pertama, Melakukan merger, konsolidasi, pengambilalihan, dan atau integrasi. Kedua, menerima merger, konsolidasi, akuisisi, atau integrasi. Kebijakan selanjutnya tentang industri perbankan yang dikeluarkan oleh otoritas selama PSBB (SP 26/ DHMS/ OJK/ IV/ 2020). Menurut Siaran Pers dalam Operasi Industri Jasa Keuangan Selama Periode Implementasi PSBB di Berbagai Daerah. Isinya bahwa OJK meminta lembaga jasa keuangan untuk bekerja dengan jumlah minimum karyawan sesuai dengan protokol kesehatan di tempat kerja. Lembaga layanan keuangan harus mematuhi prosedur PSBB untuk diimplementasikan, seperti physical distancing, mengurangi layanan dengan tatap muka dan sebagai gantinya perbankan dapat memaksimalkan penggunaan teknologi dan selalu menjaga kesehatan. Sedangkan untuk peraturan pekerjaan dari rumah, diserahkan kepada masing-masing manajemen (Otoritas Jasa Keuangan, 2019).

Penyelamatan idustri perbankan harus dilakukan karena dewasa ini perilaku bertransaksi masyarakat juga sudah bergeser dari konvensional menuju digitalisasi, mengingat masyarakat semakin masif seiring dengan pengguna smartphone yang kian banyak. Otoritas Jasa Keuangan atau OJK menjelaskan bahwa layanan perbankan digital adalah layanan atau kegiatan perbankan dengan menggunakan sarana electronik atau digital milik bank, dan/atau melalui media digital milik calon nasabah dan/atau nasabah bank, yang dilakukan secara mandiri. Digitalisasi layanan bank memungkinkan bagi nasabah dan calon nasabah untuk memperoleh layanan perbankan secara mandiri (self service) tanpa harus datang langsung ke bank (Puspa, 2020).

Penggunaan instrumen teknologi seperti perbankan digital dalam 
inovasi layanan untuk memenuhi kebutuhan nasabah dan/atau calon nasabah paling baik dipahami dalam hubungannya dengan penggunaan layanan dan bagaimana mereka merasakan layanan (Yusif, 2020). Pelayanan (service) bukan sebatas melayani, melainkan mengerti, memahami, dan merasakan. Dengan demikian, penyampaian dalam pelayanan akan mengenai heart share pelanggan. Heart share dan mind share tersebut dapat menumbuhkan loyalitas pelanggan terhadap suatu produk. Sehingga memberikan dampak positif bagi citra perusahaan. Tantangan transformasi pemanfaatan teknologi digital lebih dari sekedar menyediakan layanan online dan mobile banking, perlu berinovasi dalam menggabungkan teknologi digital dengan interaksi nasabah, dalam hal ini temuan-temuan teknologi baru tersebut haruslah mempermudah dan memberikan kenyamanan bagi pengguna dalam mengakses layanan perbankan syariah.

Diantaranya adalah perbankan digital syariah yang menjelaskan proses virtual penunjang seluruh layanan yang akan berdampak positif pada pertumbuhan bisnis secara umum. Sehingga, strategi digitalisasi hasus selalu dikembangkan oleh Bank. Digitalisasi akan berdampak positif pada pertumbuhan bisnis secara umum. Maka di era technology disruption saat ini, setiap industri harus siap bergerak menghadapi perubahanperubahan dinamis. Industri perbankan syariah pun mau tidak mau harus menyesuaikan diri dengan perkembangan teknologi yang ada, digitaliasi mengharuskan bank syariah melakukan pembaharuan layanan, mengingat peralihan dunia perbankan konvensional menjadi digital dapat meningkatkan efesiensi proses kerja dan meningkatkan kualitas layanan nasabah, dengan melakukan digitalisasi, bank sudah melakukan investasi jangka panjang untuk masa depan, dan diproyeksikan layanan digital menjadi salah satu pendorong utama pertumbuhan industri perbankan secara berkelanjutan. Hasil penelitian Asti Marlina dan Widi Ario Bimo terkait digitalisasi bank terhadap peningkatan pelayanan nasabah dan kepuasan nasabah bank menyimpulkan bahwa penggunaan teknologi digital merupakan hal yang sangat penting pada saat ini (Asti dan Bimo, 2020).

3. Analisis Dampak Covid-19 pada Bank Syariah Mandiri (BSM)

Dampak pada kegiatan intermediasi Bank Syariah Mandiri dilihat dari Perkembangan pembiayaan dan Dana Pihak Ketiga (DPK). Pembia- 
yaan dan DPK Bank Syariah Mandiri menunjukkan bahwa pembiayaan Bank Syariah Mandiri meningkat selama Januari hingga Maret 2020. Namun, DPK menunjukkan fluktuatif. Ini menunjukkan bahwa Pandemi Covid-19 mengganggu Bank dari sisi Penghimpunan DPK. Sementara itu, Pembiayaan untuk Bank Syariah Mandiri cenderung stabil. Dampak pada Manajemen Strategi Bank Syariah Mandiri.

Gambar 1 : Pembiayaan dan DPK Bank Syaraiah Mandiri (Bank Syariah Mandiri, Maret 2020)

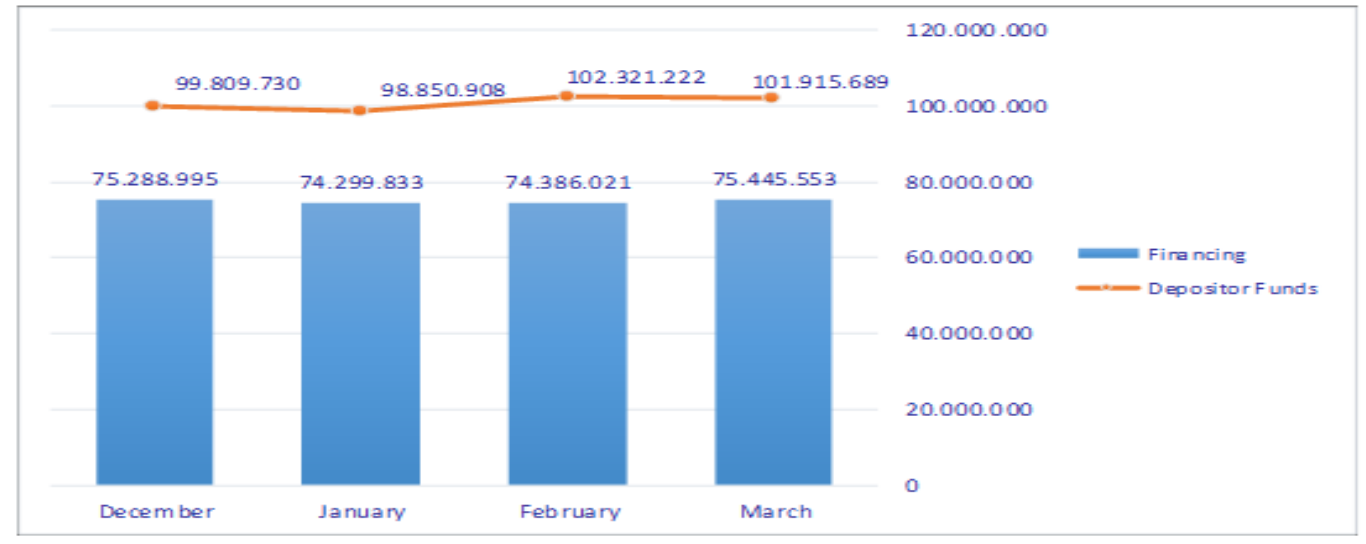

Bank Mandiri Syariah selama pandemi Covid-19 mengeluarkan kebijakan terkait dengan produk dan layanan sebagai berikut: Pertama, Mandiri Syariah Mobile (MSM). Mandiri Syariah Mobile disebut sebagai Superaps, yang mana satu aplikasi tidak hanya dapat melakukan transaksi keuangan tetapi juga menawarkan berbagi fitur-fitur tambahan diantaranya seperti fitur pembayaran zakat, sedekah, wakaf, serta ibadah melalui kemudahan mendapatkan jadwal sholat, arah kiblat, lokasi masjid, juz amma, kutipan hadits, dan lain-lain. Mandiri Syariah Mobile (MSM) dapat pula untuk transaksi e-commerce, pembayaran haji, top-up e-wallet (e-Money, Gopay, Ovo). Kedua, QRIS Transaksi menggunakan smartphone, Quick Response Code Indonesia Standard (QRIS) memudahkan dengan gadget dan teknologi untuk melakukan transaksi melalui metode pembayaran digital QRIS. Ketiga, kebijakan Stimulus Perekonomian Nasional No.11/ POJK.03/2020. Bank melonggarkan fasilitas pembiayaan kepada nasabah yang tedampak pandemi Covid-19 dalam bentuk penundaan pembayaran dan atau penurunan margin atau bagi hasil untuk jangka waktu tertentu dan persyaratannya disesuaikan dengan sektor ekonomi, kriteria, dan kondisi nasabah dengan tetap mengacu pada 
ketentuan OJK untuk nasabah terutama UKM.

\section{SIMPULAN}

Dampak Pandemi Covid-19 terhadap fungsi intermediasi perbankan, berdasarkan hasil studi pada Bank Syariah Mandiri, yaitu pembiayaan dan DPK, Bank menunjukkan adanya gejolak. Pada sisi pembiayaan Bank Syariah Mandiri selama Januari hingga Maret 2020 cenderung meningkat. Pada sisi, Penghimpunan Dana (DPK), Bank Mandiri Syariah menunjukkan fluktuatif. Dampak Pandemi Covid-19 terhadap manajemen strategi operasional perbankan. Berdasarkan hasil studi pada Bank Syariah Mandiri menunjukkan bahwa: pertama, semua bank menerapkan stimulus ekonomi terkait pembiayaan restrukturisasi untuk Nasabah yang terkena dampak pandemi Covid-19 berdasarkan POJK No.11/POJK.03/2020. Kedua, pengembangan aplikasi digital mobile banking pada kelima bank Syariah. Penelitian ini menggunakan sampel Bank Umum Syariah, Bank Syariah Mandiri di Indonesia karena keterbatasan data bank, diiharapkan penelitian selanjutnya dapat dilakukan di semua Bank Umum Syariah di Indonesia sehingga dapat menggeneralisasi hasil penelitian.

\section{UCAPAN TERIMA KASIH}

Terimakasih kami haturkan kepada kepada dewan redaksi Jurnal Hukum lmiah Ekonomi Islam (JIEI) STIE AAS Surakarta yang telah memberikan kesempatan, sehingga tulisan saya bisa diterbitkan

\section{DAFTAR RUJUKAN}

Anshari, Yahya Zakaria, Fathul Wahab, Lebanon: Darul Fikr, 1971.

Asti Marlina dan Widhi Ariyo Bimo, Digitalisasi Bank Terhadap

Peningkatan Pelayanan dan Kepuasan Nasabah Bank, Jurnal Ilmiah

Inovator, Edisi Maret 2018

Atalya Puspa, Bank Bertranformasi Menuju Digitalisasi, Media Indonesia, 9 Agustus 2020

Azis Setiawan, Sejumlah Bank Syariah Turunkan Traget Profit, dalam Republikahttps://www.republika.id/posts/7024/sejumlah-bank-syaria h-turunkantarget-profit, diakses 15 Agustus 2020

B. Yusif, "Adopting a specific innovation type versus composition of different innovation types: Case study of a Ghanaian bank," International Journal of Bank Marketing, Vol. 30, 2012, h. 218-240, 
2012

Dahlan, Abdul Aziz. et.al. (1999) Ensiklopedi Hukum Islam. Cetakan II. PT Ichtiar Baruvan Hoeve. Jakarta

Hakim, Cecep Maskanul. (1995).Konsep Pengembangan Baitul Mal. Paper Seminar Ekonomi Islam ICMI. Bandung

Kashif Malik, et. al. (2020). Covid-19 and the Future of Microfinance: Evidence and Insights from Pakistan, Forthcoming Oxford Review of Economic Policy (Special Issue).

Kementrian Kesehatan. (2020). Kasus Covid-19 on 29 April 2020. http://kemkes.go.id.

Laporan Keuangan Bulanan. Desember 2019, Januari, Februari and Maret 2020. Website Bank Syariah Mandiri.http://mandirisyariah.co.id

Laucereno, Sylke Febrina, Gubernur BI: Kami minta perbankan segera turunkan bunga kredit! Diakses melalui https://finance. detik.com/moneter/d-4951911

Laporan Keuangan Bulanan. Desember 2019, Januari, Februari and Maret 2020. Website Bank Victoria Syariah, http://bankvictoriasyariah.co.id

Montly Financial Statement December 2019, January, February and March 2020 on Website Bank Syariah Mandiri, http://mandirisyariah.co.id

Michael McAleer, "Prevention Is Better Than the Cure: Risk Management of COVID-19,"Journal of Risk Financial Management 13 Mahinda Mailagaha Kumbure, et al. (2020).

Nazaruddin abdul wahib. Sukuk memahami \& membedah obligasi pada perbankan syariah. Yogyakarta: Ar-Ruzz Media. 2010.

Otoritas Jasa Keuangan. (2019).Statistik Perbankan Indonesia January 2019.

Otoritas Jasa Keuangan. (2020). POJK No. 11/POJK.03/2020 tentang Stimulus Perekonomian Nasional Sebagai Kebijakan Countercyclical Dampak Penyebaran Coronavirus Disease

Otoritas Jasa Keuangan. (2020). Siaran Pers OJK SP 26/DHMS/OJK/IV/ 2020 tentang Siaran Pers Operasional Industri Jasa Keuangan Dalam Masa Penerapan Pembatasan Sosial Berskala Besar (PSBB) Di Berbagai Daerah

Otoritas Jasa Keuangan. (2020). POJK No. 18 / POJK.03/2020 tentang Perintah Tertulis untuk Penanganan Permasalahan Bank

Relation between managerial cognition and industrial performance: An Assessment with Strategic Cognitive Maps using Fuzzy-set qualitative comparative Analysis. Journal of Business Research.Elsevier 
Sugiyono, Metode Penelitian Kuantitatif, Kualitatif dan RED, (Bandung : Alfabeta, 2011)

Syukra, Ridho. (2020, 1 Mei). "pasca covid-19, Laju Pertumbuhan Ekonomi Indonesia Tak Langsung Pulih". Diakses pada tanggal 05 Mei 2020 dalam https://investor.id/business/pasca-covid19-laju-pertum buhanekonomi-indonesia-tak-langsung-100-pulih

Tim DD-FES-BMT. (1997) Pedoman Kemitraan Dompet Dhuafa Republika-FES-BMT. Dompet Dhuafa Republika. Jakarta

Yuliana, Yuliana. "Corona virus diseases (Covid-19); Sebuah tinjauan literatur". Dalam Jurnal Fakultas Kedokteran Universitas Lampung. Vol. 2, No. 1. 2020.

Zuhaili, Wahbah al-Figh al-Islami wa Adilltuhu, Dar Al-Fikr, Damaskus Cet.III, 1989

Zbigniew Korzeb and Reyes Samaniego-Medina, Sustainability Performance: A Comparative Analysis in The Polish Banking Sector, Sustainability, 2019 